\title{
Glandular trichome density and essential oil composition in leaves and inflorescences of Lippia origanoides Kunth (Verbenaceae) in the Brazilian Cerrado
}

\author{
LUIZ R.S. TOZIN ${ }^{1}$, MARCIA O.M. MARQUES ${ }^{2}$ \\ and TATIANE M. RODRIGUES ${ }^{1}$ \\ ${ }^{1}$ Universidade Estadual Paulista/UNESP, Instituto de Biociências de Botucatu, IBB, \\ Departamento de Botânica, Distrito de Rubião Júnior, s/n, 18618-970 Botucatu, SP, Brasil \\ ${ }^{2}$ Instituto Agronômico de Campinas/IAC, Laboratório de Produtos Naturais, \\ Av. Barão de Itapura, 1481, 13020-902 Campinas, SP, Brasil
}

Manuscript received on August 5, 2014; accepted for publication on November 25, 2014

\begin{abstract}
The essential oils from leaves and inflorescences of Lippia origanoides Kunth present aromatic and medicinal potential and have been used to treat several diseases, including melanoma. In Brazil, $L$. origanoides is commonly found in campo cerrado and cerrado stricto sensu, physiognomies featured mainly by the differential light conditions to which short and medium-sized plants are subjected. Our aim was to investigate the glandular trichome density and the yield and chemical composition of the essential oils in leaves and inflorescences of L. origanoides from campo cerrado and cerrado stricto sensu. For glandular density analysis, leaves and inflorescences were processed according to conventional techniques for scanning electron microscopy. The essential oils of leaves and inflorescences were obtained by hydrodistillation and identified with gas chromatography. Bracts and sepals showed the highest glandular density, followed by petals and leaves. The glandular density in the abaxial leaf surface was higher in individuals from the campo cerrado. In both populations the essential oil yield was higher in inflorescences than in leaves. The chemical composition of the essential oils varied among individuals from different areas and inside a same population. Our results demonstrated the chemical plasticity of L. origanoides suggesting the importance of monitoring its popular use.
\end{abstract}

Key words: campo cerrado, cerrado stricto sensu, external glands, terpenes.

\section{INTRODUCTION}

Species of Verbenaceae are known for the presence of glandular trichomes that secrete essential oils. Many of these species are widely exploited by drug manufacturers and used in popular medicine (Judd et al. 2009, Pascual et al. 2001, Souza and Lorenzi

Correspondence to: Tatiane Maria Rodrigues

E-mail: tatiane@ibb.unesp.br
2008). Lippia origanoides Kunth, a native shrub of the Brazilian Cerrado, is widely distributed in South America from Guiana to northern Argentina, and also occurs in Central America (O'Leary et al. 2012). The essential oil extracted from leaves of L. origanoides shows antimicrobial, antiviral, acaricidal, antioxidant, antibacterial and antiinflammatory activities (Cavalcanti et al. 2010, 
Gomes et al. 2012, Oliveira et al. 2007, RochaGuzmán et al. 2007, Stashenko et al. 2010, 2013, Veras et al. 2013). Different chemotypes of $L$. origanoides were reported in literature and p-cimene, thymol and carvacrol are the major components most commonly found (Cavalcanti et al. 2010, Oliveira et al. 2007, Stashenko et al. 2010, 2013).

In the Brazilian Cerrado, L. origanoides is commonly found in areas of campo cerrado and cerrado stricto sensu. These Cerrado physiognomies are featured mainly by the differential light intensity that reaches the short and medium-sized plants. The cerrado stricto sensu is characterized by the occurrence of medium-sized trees, scattered shrubs and some grasses. In this area the individuals of L. origanoides are shaded by nearby trees in the early hours of the morning and in late afternoon. In the campo cerrado, grasses and small shrubs are predominant, with some sparse trees (Maroni et al. 2006), and individuals of L. origanoides are exposed to full sunlight throughout the day.

Studies indicate that both yield and chemical composition of the essential oils and the glandular trichome density, can be influenced by environmental factors, including herbivory, temperature, water availability, altitude, circadian cycle, seasonality, and light intensity, among others (Argyropoulou et al. 2007, Gianfagna et al. 1992, Gobbo-Neto and Lopes 2007, Gonzáles et al. 2008, Juliani Jr et al. 2002, MartínezNatarén et al. 2011, Pérez-Estrada et al. 2000, Viljoen et al. 2005, Werker 2000). Whether the different organs in a same plant respond similarly to the environmental fluctuations concerning the essential oil composition is still unknown.

Since leaves and inflorescences of $L$. origanoides are exhaustively exploited by people living in Cerrado areas in Brazil for medicinal purposes, knowledge on the occurrence of variation in the essential oil composition in plants living in different environmental conditions can be important in order to avoid it being misused.
We investigated the density of the glandular trichomes and the yield and chemical composition of essential oils in leaves and inflorescences of L. origanoides from campo cerrado and cerrado stricto sensu.

\section{MATERIALS AND METHODS}

StUdy AREA AND Plant MATERIAL

Two wild populations of $L$. origanoides were located in two different Cerrado physiognomies, cerrado stricto sensu (S 22 49'11.39" and W $\left.48^{\circ} 44^{\prime} 51.18^{\prime \prime}\right)$ and campo cerrado (S 22 53'29.82' and W 48'29'25.81'), both in midwestern state of São Paulo, Brazil. The climate of both areas is Cwa, according to Köppen.

Data on the temperature and relative humidity from November 2012 through March 2013 were obtained from meteorological stations in the cerrado stricto sensu and campo cerrado areas. The photosynthetic photon flux density (PPFD) was measured with a PAM fluorometer on successive days. The altitude data were recorded with a GPS.

Table I shows the data for temperature, relative humidity, PPFD and altitude in both areas.

TABLE I

Environmental data from areas of cerrado sensu stricto and campo cerrado in São Paulo State, Brazil.

\begin{tabular}{lcc}
\hline & $\begin{array}{c}\text { cerrado stricto } \\
\text { sensu }\end{array}$ & $\begin{array}{c}\text { campo } \\
\text { cerrado }\end{array}$ \\
\hline Temperature $\left({ }^{\circ} \mathrm{C}\right)$ & 22.5 & 21.7 \\
Air relative humidity $(\%)$ & 82.0 & 79.5 \\
PPFD $\left(\mu \mathrm{mol} . \mathrm{m}^{-2} \cdot \mathrm{s}^{-1}\right)$ & 1837 & 2045 \\
Altitude $(\mathrm{m})$ & 719 & 833 \\
\hline
\end{tabular}

Twelve adult plants of $L$. origanoides were sampled in each population. Leaves and inflorescences were collected during the summer, in February 2013. All individuals were in the same phenological stage.

Vouchers were deposited in the Herbarium Irina Delanova Gemtchújnicov (BOTU), Department of Botany, Universidade Estadual Paulista (UNESP), Botucatu, state of São Paulo. 


\section{DENSITY OF GLANDULAR TRICHOMES}

To evaluate the density of glandular trichomes, two fully expanded leaves were collected from each plant in both populations. To estimate the density of glandular trichomes in reproductive organs, two inflorescences were collected from each individual in the campo cerrado.

Samples of flowers and the middle part of leaf blades were fixed in glutaraldehyde $(2.5 \%$ with 0.1 $\mathrm{M}$ phosphate buffer, $\mathrm{pH} 7.3$, overnight at $4{ }^{\circ} \mathrm{C}$ ), dehydrated in a graduated acetone series, criticalpoint dried, mounted on aluminum stubs, goldcoated (Robards 1978), and examined with a Fei Quanta scanning electron microscope.

The glandular density in leaves and flowers was calculated in $1 \mathrm{~mm}^{2}$ using the Scandium software with an image-capture system coupled to the scanning electron microscope. We compared the glandular density between a) the adaxial and abaxial leaf surfaces in individuals from the same population; b) leaves from different populations; and c) leaves and floral parts (bracts, sepals, petals) from the same population. The data were submitted to ANOVA followed by Tukey test, at a $5 \%$ probability level.

YIELD AND CHEMICAL COMPOSITION OF THE ESSENTIAL OILS

For the essential oil analyses, leaves and inflorescences were collected from four individuals growing in the cerrado stricto sensu (numbered 1 to 4) and from three individuals growing in the campo cerrado (numbered 1 to 3 ). Individual number 3 in the campo cerrado was located on an ant colony.

The samples were dried at $40{ }^{\circ} \mathrm{C}$ and were subjected to hydrodistillation in a Clevenger-type apparatus (Craveiro et al. 1981) for $2 \mathrm{~h}$.

The qualitative analysis of the essential oil was performed on a gas chromatograph coupled to a mass spectrometer (CG-MS, Shimadzu, QP5000), with an OV-5 fused silica capillary column (30 m x $0.25 \mathrm{~mm} \times 0.25 \mu \mathrm{m}$, Ohio Valley Specialty Chemical, Inc.), operating at an MS ionization voltage of $70 \mathrm{eV}$, with helium as the carrier gas $(1.0 \mathrm{~mL} / \mathrm{min}$.). The following chromatography conditions were used: injector at $240{ }^{\circ} \mathrm{C}$, detector at $230{ }^{\circ} \mathrm{C}$, injection volume: $1 \mu \mathrm{L}$ of solution $(1 \mathrm{mg}$ of essential oil/ $1 \mathrm{~mL}$ of ethyl acetate), split $1 / 20$, and the temperature program: $60{ }^{\circ} \mathrm{C}-240{ }^{\circ} \mathrm{C}, 3{ }^{\circ} \mathrm{C} /$ $\mathrm{min}$. The compounds were identified by comparison of the acquired mass spectra with those stored in the GC/MS database of the system (NIST $62 \mathrm{lib}$.) and retention indices (Adams 2007). The retention indices (RI) were obtained from the injection of a mixture of $n$-alcanes (Sigma-Aldrich, $\mathrm{C}_{9}-\mathrm{C}_{24}$ ), employing the same temperature program conditions described above for GC/MS, applying the equation of Van den Dool and Kratz (1963).

The separation and quantification (area normalization method) of the substances were carried out by gas chromatography (GC-FID, Shimadzu, GC2010/AOC-20i), equipped with a flame ionizer, using a DB-5 capillary column (J and W Scientific; $30 \mathrm{~m} \times 0.25 \mathrm{~mm} \times 0.25 \mu \mathrm{m})$, with helium as the carrier gas $(1.0 \mathrm{~mL} / \mathrm{min})$, temperature injector at 240 ${ }^{\circ} \mathrm{C}$, detector at $230{ }^{\circ} \mathrm{C}$, split $1 / 20$, injection volume $1 \mu \mathrm{L}$ of solution ( $1 \mathrm{mg}$ essential oil/1 $\mathrm{mL}$ ethyl acetate). The following chromatography conditions were used: $60{ }^{\circ} \mathrm{C}-160{ }^{\circ} \mathrm{C}, 5^{\circ} \mathrm{C} / \mathrm{min} ; 160{ }^{\circ} \mathrm{C}-230$ ${ }^{\circ} \mathrm{C}, 3{ }^{\circ} \mathrm{C} / \mathrm{min} ; 230{ }^{\circ} \mathrm{C}-280{ }^{\circ} \mathrm{C}, 10{ }^{\circ} \mathrm{C} / \mathrm{min}$.

The yield of essential oil was analyzed using factorial analysis, and compared among the plant organs and populations by ANOVA, followed by Tukey test at a $5 \%$ probability level.

\section{RESULTS}

DistribUtion AND DENSITY OF GLANDULAR TRICHOME

Glandular trichomes were observed in both leaf (Fig. 1A, B) and bract (Fig. 1C) surfaces, as well as the abaxial side of sepals (Fig. 1D) and petals (Fig. 1E) of L. origanoides. In the petals, these glands occurred exclusively in the distal region.

In the individuals from the campo cerrado, the glandular density was higher in the inflorescences than in the leaves $\left(\mathrm{F}_{(4,55)}=144.3919 ; \mathrm{P}<0.00001\right)$ 

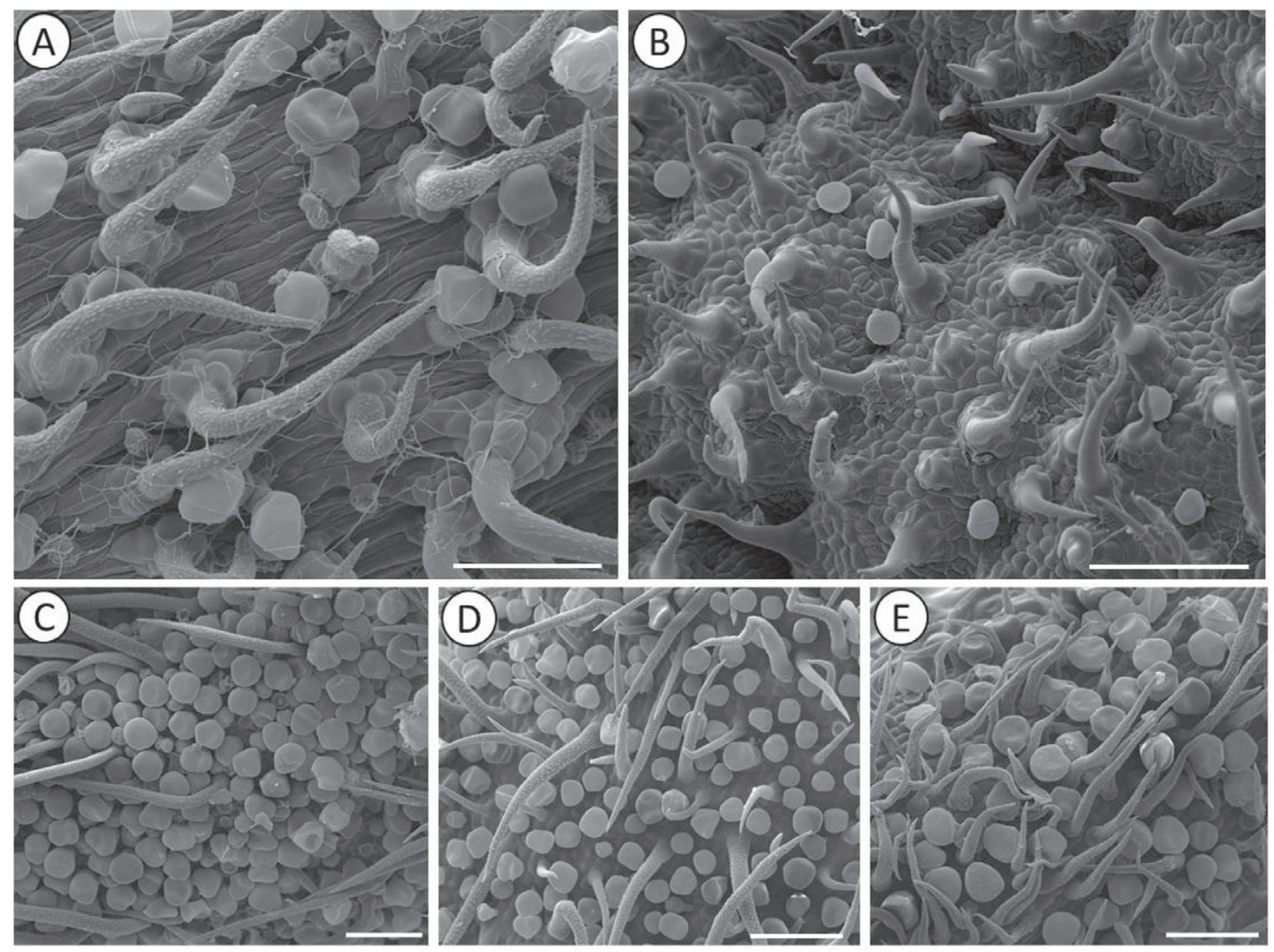

Figure 1 - Scanning electron micrographs of leaves and floral parts of Lippia origanoides Kunth showing glandular and nonglandular trichomes. A. Abaxial leaf surface. B. Adaxial leaf surface. C. Abaxial bract surface. D. Abaxial sepal surface. E. Abaxial petal surface. Scale bars: A-E $=100 \mu \mathrm{m} ; \mathrm{B}=200 \mu \mathrm{m}$.

(Table II). Bracts and sepals were the organs with the highest glandular density (Table II). The density of glandular trichomes was three to four times higher on the abaxial surface of the leaf (Fig. 1A) than on the adaxial (Fig. 1B) for individuals from both the campo cerrado and the cerrado stricto sensu (Table II).

The abaxial leaf surface of individuals from the campo cerrado showed a higher density of glandular trichomes in comparison to individuals from the cerrado stricto sensu $\left(\mathrm{F}_{(1,22)}=15.6354\right.$; $\mathrm{P}=0.0009$ ). Differences in the glandular density were not observed for the adaxial leaf surfaces of individuals from the different populations $\left(\mathrm{F}_{(1,22)}=1.1297 ; \mathrm{P}=0.2998\right)$ (Table II).
Yield AND ChemicAl Composition of the EsSENTIAL OIL

The yield of the essential oil of $L$. origanoides was higher in inflorescences than in the leaves (Fig. 2) in individuals from both cerrado physiognomies $\left(\mathrm{F}_{(3,8)}=22.7906 ; \mathrm{P}<0.0001\right)$ (Fig. 2). No significant differences were observed in the oil yield between individuals from the cerrado stricto sensu and the campo cerrado, for both leaves $(\mathrm{P}=0.390)$ and inflorescences $(\mathrm{P}=0.233)$.

During the analysis of the essential oil yield, the samples from individual 3 (the one that was located on an ant colony in the field) from the campo cerrado were not used, due to the discrepant values obtained for its inflorescences (1.98) and leaves (3.97). 
TABLE II

Glandular density $\left(\mathrm{mm}^{2}\right)$ in leaf blades and inflorescences of Lippia origanoides Kunth from two physiognomies of the Brazilian Cerrado.

\begin{tabular}{lcc}
\hline \multirow{2}{*}{ Organ } & \multicolumn{2}{c}{ Glandular density } \\
\cline { 2 - 3 } & campo cerrado & cerrado stricto sensu \\
\hline Bract (abaxial surface) & $624.00 \mathrm{~A}$ & - \\
Sepal (abaxial surface) & $544.42 \mathrm{~A}$ & - \\
Petal (abaxial surface) & $271.85 \mathrm{~B}$ & - \\
Leaf (abaxial surface) & $97.62 \mathrm{Ca}$ & $69.52 \mathrm{Ab}$ \\
Leaf (adaxial surface) & $21.43 \mathrm{Da}$ & $19.16 \mathrm{Ba}$ \\
\hline
\end{tabular}

Means followed by different capital letters indicate statistical differences in the glandular density among organs and different lowercase letters indicate statistical differences in the glandular density between populations (Tukey test $p<0.05$ ).

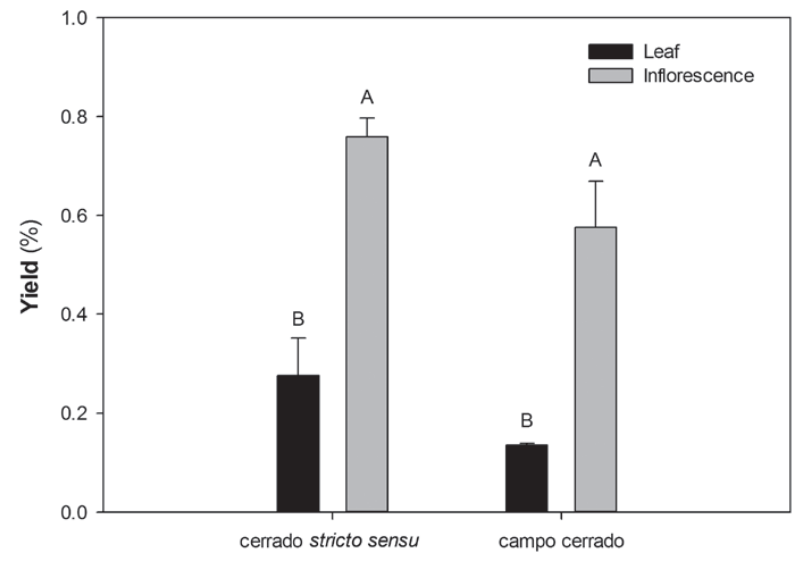

Figure 2 - Yield of essential oil of leaves and inflorescences of Lippia origanoides Kunth from two populations in the Cerrado (Means followed by different letters indicate statistical differences in the essential oil yield between organs inside a same population and between different populations by Tukey test at 5\% significance level).

We identified 49 substances in the essential oil extracted from leaves and inflorescences of $L$. origanoides. The amount of substances found in the inflorescences was higher than in the leaves, in both populations. The major compounds varied between the populations, among the individuals from the same population, and between the organs of the same individual (Table III).

In the cerrado stricto sensu, trans-caryophyllene was the major compound in the inflorescences of individual 1 (63.4\%), 2 (34.2\%) and 4 (39.3\%), whereas $\alpha$-humulene was the major compound in individual 3 (58.7\%). Concerning the leaves, transcaryophyllene $(33.7 \%)$ and $\delta$-cadinene $(10.3 \%)$ were the major compounds in individual 2; individuals 3 and 4 showed $\alpha$-humulene $(66.3 \%$ and $40.0 \%$, respectively) and trans-caryophyllene $(9.5 \%$ and $24.9 \%$, respectively) as their major compounds.

In the campo cerrado, $\alpha$-pinene $(27.2 \%)$ and trans-caryophyllene $(38.6 \%)$ were the major compounds in the inflorescences, and transcaryophyllene $(60.6 \%)$ in the leaves of individual 1. $\beta$-elemene was the major compound in the inflorescences (10.2\%), and $\alpha$-humulene in the leaves (10.3\%) of individual 2; trans-caryophyllene, $\gamma$-selinene and 7-epi- $\alpha$-selinene were the majority compounds in both the inflorescences $(11.2 \%$, $14.9 \%$ and $10.5 \%)$ and the leaves $(9.5 \%, 16.7 \%$ and $13.5 \%$ ) in this individual. 1,8 cineole was the major compound in both the inflorescences $(52.2 \%)$ and the leaves (58.2\%) of individual 3; differently from the other individuals, oxygenated monoterpenes were predominant in the inflorescences $(61.8 \%)$ and leaves $(71.3 \%)$ of this individual (Table III).

\section{DISCUSSION}

We have found a higher density of glandular trichomes on the abaxial leaf surface of $L$. origanoides plants growing in the campo cerrado; in this area the relative humidity was lower and the altitude and PPFD were higher. Little is known 
TABLE III

Chemical composition of the essential oils (\%) from inflorescences and leaves of Lippia origanoides Kunth from cerrado stricto sensu and campo cerrado in São Paulo state, Brazil.

\begin{tabular}{|c|c|c|c|c|c|c|c|c|c|c|c|c|c|c|c|}
\hline \multirow{3}{*}{ Compound } & \multicolumn{7}{|c|}{ Inflorescences } & \multicolumn{6}{|c|}{ Leaves } & \multirow{3}{*}{ RI* } & \multirow{3}{*}{$\mathrm{RI} * *$} \\
\hline & \multicolumn{4}{|c|}{ cerrado stricto sensu } & \multicolumn{3}{|c|}{ campo cerrado } & \multicolumn{3}{|c|}{$\begin{array}{l}\text { cerrado stricto } \\
\text { sensu }\end{array}$} & \multicolumn{3}{|c|}{ campo cerrado } & & \\
\hline & 1.0 & 2.0 & 3.0 & 4.0 & 1.0 & 2.0 & 3.0 & 2.0 & 3.0 & 4.0 & 1.0 & 2.0 & 3.0 & & \\
\hline \multicolumn{16}{|c|}{ Hydrocarbon Monoterpenes } \\
\hline$\alpha$-thujenew & nd & nd & nd & nd & nd & nd & 0.6 & nd & nd & nd & nd & nd & 0.8 & 927 & 930 \\
\hline$\alpha$-pinene & 3.7 & 0.8 & 8.4 & nd & 27.2 & nd & 4.6 & 0.5 & 0.7 & nd & 2.4 & nd & 4.2 & 934 & 939 \\
\hline camphene & 1.2 & 3.0 & 1.3 & 0.4 & 2.4 & 0.2 & 0.2 & 1.5 & 0.1 & 0.1 & 0.2 & nd & $\operatorname{tr}$ & 948 & 954 \\
\hline sabinene & nd & nd & nd & nd & nd & nd & 5.8 & nd & nd & nd & nd & 0.7 & 4.2 & 975 & 975 \\
\hline$\beta$-pinene & nd & nd & nd & nd & 1.3 & nd & 2.3 & nd & nd & nd & nd & nd & 2.3 & 977 & 979 \\
\hline myrcene & nd & 0.6 & 0.5 & nd & 0.7 & $\operatorname{tr}$ & 1.5 & $\operatorname{tr}$ & $\operatorname{tr}$ & nd & nd & nd & 1.5 & 991 & 990 \\
\hline$\alpha$-phellandrene & nd & nd & 0.4 & nd & $\operatorname{tr}$ & nd & 0.3 & nd & nd & nd & nd & nd & 0.4 & 1006 & 1002 \\
\hline$\alpha$-terpinene & nd & 0.6 & $\operatorname{tr}$ & nd & nd & nd & nd & nd & nd & nd & nd & nd & 0.6 & 1017 & 1017 \\
\hline p-cymene & 1.0 & 1.9 & 0.3 & $\operatorname{tr}$ & 2.1 & 0.2 & 1.6 & 0.9 & nd & nd & nd & nd & 1.0 & 1024 & 1024 \\
\hline limonene & 0.4 & 1.9 & 3.0 & nd & nd & nd & nd & nd & nd & nd & 0.4 & 0.2 & 1.8 & 1029 & 1029 \\
\hline$Z$ - $\beta$-ocymene & nd & nd & nd & nd & nd & nd & nd & 1.4 & nd & 0.3 & nd & nd & nd & 1037 & 1037 \\
\hline$E$ - $\beta$-ocymene & nd & 7.9 & 1.8 & nd & nd & 1.7 & $\operatorname{tr}$ & 4.5 & 0.2 & $\operatorname{tr}$ & nd & 0.8 & $\operatorname{tr}$ & 1047 & 1050 \\
\hline$\gamma$-terpinene & $\operatorname{tr}$ & 5.1 & 1.2 & nd & nd & nd & 1.9 & 0.3 & nd & nd & nd & nd & 1.3 & 1058 & 1059 \\
\hline terpinolene & nd & 0.2 & $\operatorname{tr}$ & nd & $\operatorname{tr}$ & nd & 0.3 & $\operatorname{tr}$ & nd & nd & nd & nd & 0.2 & 1089 & 1088 \\
\hline \multicolumn{16}{|c|}{ Oxygenated Monoterpenes } \\
\hline 1-octen-3-ol & 0.2 & 0.3 & 0.5 & nd & nd & nd & nd & 0.9 & $\operatorname{tr}$ & 0.4 & nd & nd & nd & 977 & 979 \\
\hline 1,8 cineole & 0.4 & 8.7 & 0.4 & 0.3 & 0.2 & 0.3 & 52.2 & 4.3 & 1.3 & nd & nd & nd & 58.2 & 1031 & 1031 \\
\hline linalool & 1.2 & 5.2 & 0.8 & 3.7 & 1.9 & 5.7 & 0.6 & 1.1 & $\operatorname{tr}$ & 2.8 & 0.7 & 4.1 & 1.6 & 1100 & 1096 \\
\hline borneol & nd & 1.2 & $\operatorname{tr}$ & nd & $\operatorname{tr}$ & nd & 0.5 & 0.3 & $\operatorname{tr}$ & nd & nd & nd & 0.6 & 1165 & 1169 \\
\hline terpinen-4-ol & nd & 0.6 & nd & nd & nd & nd & 1.8 & $\operatorname{tr}$ & nd & nd & nd & nd & 2.4 & 1177 & 1177 \\
\hline$\alpha$-terpineol & nd & 1.0 & nd & nd & nd & nd & 6.7 & $\operatorname{tr}$ & nd & nd & nd & nd & 8.6 & 1190 & 1188 \\
\hline \multicolumn{16}{|c|}{ Hydrogenated Sesquiterpenes } \\
\hline$\alpha$-copaene & 5.3 & 5.1 & 3.4 & 5.4 & 3.7 & 1.0 & $\operatorname{tr}$ & 8.5 & 4.2 & 4.6 & 8.5 & 1.4 & nd & 1378 & 1376 \\
\hline$\beta$-elemene & 4.2 & 1.6 & 1.4 & 1.7 & 3.3 & 10.2 & 0.5 & nd & nd & nd & $\operatorname{tr}$ & 0.5 & nd & 1394 & 1390 \\
\hline$\alpha$-gurjunene & nd & 0.3 & $\operatorname{tr}$ & 0.2 & nd & nd & nd & 0.6 & nd & 0.2 & nd & nd & nd & 1411 & 1409 \\
\hline trans-caryophyllene & 63.4 & 34.2 & 12.7 & 39.3 & 38.6 & 11.2 & 3.9 & 33.7 & 9.5 & 24.9 & 60.6 & 9.5 & 2.5 & 1422 & 1419 \\
\hline$\alpha$-guaiene & nd & 0.9 & nd & nd & nd & nd & 0.3 & 1.8 & nd & nd & nd & $\operatorname{tr}$ & 0.2 & 1440 & 1439 \\
\hline aromadendrene & nd & nd & nd & nd & nd & 0.6 & nd & nd & nd & nd & nd & 0.6 & nd & 1446 & 1441 \\
\hline$\alpha$-humulene & 3.7 & 2.3 & 58.7 & 35.0 & 2.2 & 8.3 & 0.3 & 2.7 & 66.3 & 40.0 & 3.7 & 10.3 & $\operatorname{tr}$ & 1455 & 1554 \\
\hline allo-aromadendrene & 0.6 & nd & $\operatorname{tr}$ & 0.8 & 0.2 & $\operatorname{tr}$ & $\operatorname{tr}$ & 0.3 & 0.3 & 0.7 & 0.5 & $\operatorname{tr}$ & $\operatorname{tr}$ & 1462 & 1460 \\
\hline$\gamma$-muurolene & 1.0 & 0.4 & 0.5 & 1.0 & nd & 1.3 & nd & 0.9 & nd & nd & nd & 1.2 & nd & 1475 & 1479 \\
\hline germacrene D & 1.6 & 0.6 & 0.3 & 0.9 & 0.7 & 0.7 & 0.6 & 1.0 & 0.6 & 0.9 & 1.2 & nd & nd & 1478 & 1485 \\
\hline$\gamma$-selinene & nd & nd & nd & nd & nd & 14.9 & nd & $\operatorname{tr}$ & nd & nd & nd & 16.7 & nd & 1481 & 1498 \\
\hline$\beta$-selinene & 0.9 & 0.7 & 1.3 & 0.5 & 1.1 & 3.7 & nd & $\operatorname{tr}$ & nd & nd & $\operatorname{tr}$ & 3.1 & nd & 1487 & 1492 \\
\hline valencene & nd & nd & nd & nd & nd & 3.0 & nd & nd & nd & nd & nd & 3.6 & nd & 1490 & 1496 \\
\hline$\alpha$-selinene & nd & nd & nd & nd & nd & 6.6 & nd & 0.9 & 0.3 & nd & $\operatorname{tr}$ & 6.0 & nd & 1496 & 1498 \\
\hline bicyclogermacrene & 0.2 & 0.5 & $\operatorname{tr}$ & $\operatorname{tr}$ & 4.1 & nd & 5.3 & nd & nd & nd & nd & nd & 2.2 & 1497 & 1500 \\
\hline$\alpha$-muurolene & nd & nd & nd & 1.7 & nd & nd & nd & 1.6 & 0.7 & 0.9 & 1.4 & nd & nd & 1501 & 1500 \\
\hline germacrene A & 1.8 & 2.4 & $\operatorname{tr}$ & nd & nd & 1.0 & nd & 0.4 & nd & nd & nd & nd & nd & 1506 & 1509 \\
\hline 7-epi- $\alpha$-selinene & nd & nd & nd & nd & nd & 10.5 & nd & nd & nd & nd & nd & 13.5 & nd & 1514 & 1522 \\
\hline$\delta$-cadinene & 2.2 & 5.4 & 1.0 & 2.2 & 0.8 & 0.2 & $\operatorname{tr}$ & 10.3 & 1.5 & 2.5 & 2.9 & 0.4 & nd & 1525 & 1513 \\
\hline trans-cadina-1,4-diene & nd & $\operatorname{tr}$ & nd & nd & nd & nd & nd & 0.3 & nd & nd & nd & nd & nd & 1534 & 1534 \\
\hline germacrene B & $\operatorname{tr}$ & nd & $\operatorname{tr}$ & nd & nd & 0.5 & nd & nd & nd & nd & nd & 0.5 & nd & 1553 & 1561 \\
\hline
\end{tabular}




\begin{tabular}{|c|c|c|c|c|c|c|c|c|c|c|c|c|c|c|c|}
\hline \multicolumn{16}{|c|}{ Oxygenated Sesquiterpenes } \\
\hline spathulenol & nd & $\operatorname{tr}$ & nd & 0.3 & 1.0 & nd & 3.4 & nd & nd & 0.3 & nd & nd & 2.0 & 1578 & 1578 \\
\hline caryophyllene oxide & 2.1 & 3.6 & 0.5 & 2.3 & 5.8 & 1.4 & 2.3 & 6.0 & 0.7 & 3.9 & 6.2 & 1.0 & 2.5 & 1583 & 1583 \\
\hline humulene epoxide II & $\operatorname{tr}$ & nd & nd & nd & $\operatorname{tr}$ & 1.1 & nd & $\operatorname{tr}$ & 5.0 & 4.6 & 2.8 & 1.2 & nd & 1610 & 1608 \\
\hline 1-epi-cubenol & 0.3 & nd & 1.2 & 1.5 & nd & 0.8 & nd & 4.5 & 1.7 & 2.2 & nd & 1.7 & nd & 1629 & 1628 \\
\hline cubenol & 0.6 & 1.4 & $\operatorname{tr}$ & 0.5 & 0.6 & nd & 0.7 & 0.3 & 0.3 & 2.4 & 1.1 & 2.0 & $\operatorname{tr}$ & 1643 & 1646 \\
\hline$\alpha$-muurolol & $\operatorname{tr}$ & 0.8 & $\operatorname{tr}$ & 0.5 & nd & 0.7 & nd & 5.5 & 0.2 & 1.0 & 0.7 & 0.6 & nd & 1646 & 1646 \\
\hline selin-11-en-4- $\alpha$-ol & nd & nd & nd & nd & nd & 5.8 & nd & $\operatorname{tr}$ & nd & nd & nd & 8.1 & nd & 1654 & $1652 * * *$ \\
\hline$\alpha$-cadinol & 2.6 & 0.5 & 0.6 & 1.6 & 2.0 & 5.9 & nd & 1.1 & 1.3 & 2.8 & nd & 8.6 & $\operatorname{tr}$ & 1655 & 1654 \\
\hline $\begin{array}{l}\text { Hydrocarbon } \\
\text { Monoterpenes }\end{array}$ & 6.3 & 21.9 & 16.9 & 0.4 & 33.7 & 2.0 & 18.9 & 9.1 & 1.0 & 0.4 & 3.0 & 1.8 & 18.2 & & \\
\hline $\begin{array}{l}\text { Oxygenated } \\
\text { Monoterpenes }\end{array}$ & 1.8 & 16.9 & 1.7 & 4.1 & 2.1 & 6.0 & 61.8 & 6.6 & 1.3 & 3.2 & 0.7 & 4.1 & 71.3 & & \\
\hline $\begin{array}{l}\text { Hydrogenated } \\
\text { Sesquiterpenes }\end{array}$ & 84.8 & 54.2 & 79.1 & 88.5 & 54.6 & 73.6 & 10.9 & 62.9 & 83.3 & 74.7 & 78.8 & 67.1 & 4.9 & & \\
\hline $\begin{array}{l}\text { Oxygenated } \\
\text { Sesquiterpenes }\end{array}$ & 5.5 & 6.2 & 2.3 & 6.5 & 9.4 & 15.6 & 6.3 & 17.4 & 9.2 & 16.9 & 10.7 & 23.2 & 4.5 & & \\
\hline Total identified & 98.4 & 99.2 & 100.0 & 99.5 & 99.7 & 97.2 & 97.9 & 95.9 & 94.9 & 95.2 & 93.3 & 96.0 & 98.9 & & \\
\hline
\end{tabular}

$\mathrm{RI}^{*}=$ Retention index calculated; IR**= Retention index (Adams 2007); nd $=$ not detected; $\operatorname{tr}=\operatorname{trace}(\operatorname{tr} \leq 0.13) . * * *$ Retention index obtained on the website: www.pherobase.com

about the influence of exogenous factors on the origin of secretory structures in plants. Studies have reported on the effects of light, temperature, altitude, and availability of nutrients, among others, on the glandular density in different plant species (Gianfagna et al. 1992, Horgan et al. 2009, PérezEstrada et al. 2000). In drier environments, the density of trichomes on leaves can be higher than in plants of the same species growing in wetter situations (Pérez-Estrada et al. 2000). Similarly, light intensity can positively influence the glandular trichomes (Pérez-Estrada et al. 2000, Yamaura et al. 1989). According to Pérez-Estrada et al. (2000), in addition to playing a defensive role against biotic agents, glandular trichomes can help to reflect sunlight and minimize water loss.

Although the PPFD was similar between the areas, plant density in the cerrado stricto sensu is higher, and at certain periods of the day the individuals can be shaded. This does not occur in the campo cerrado, where shorter herbaceous species predominate. The shading of $L$. origanoides plants in the cerrado stricto sensu may be related to the lower glandular density of their leaves, since plants under more intense radiation tend to have higher glandular density as a protective mechanism (Gianfagna et al. 1992, Pérez-Estrada et al. 2000). In addition, the higher density of glandular trichomes on leaves of L. origanoides plants in the campo cerrado may be related to the higher altitude of this area.

The influence of altitude on the abundance of glandular structures was evaluated by Sheue et al. (2003), who found a higher density of internal glands in individuals of Pinus taiwanensis in middle altitudes (1000 to $2500 \mathrm{~m}$ ), in comparison with plants at lower $(700 \mathrm{~m})$ or higher $(3000 \mathrm{~m})$ altitudes. According to the authors, variation in the number of glands can result from genetic and environmental interactions. This suggests that variations in the glandular density in individuals of $L$. origanoides growing in the campo cerrado and the cerrado stricto sensu may result from interactions between environmental or microenvironmental factors and genetic factors.

Although the glandular density differed in leaves from individuals of $L$. origanoides living in the campo cerrado and in the cerrado stricto sensu, the yields of essential oil from plants living in the two environments were similar. This may be related to the mixed chemical nature of the 
secretion produced by the glandular trichomes of $L$. origanoides. Besides lipid substances, Tozin et al. (2015), using histochemical methods, detected the presence of polysaccharides, phenolic compounds, proteins, and alkaloids, among others, in the glandular trichomes of this species. The mixed nature of the secretion produced by the trichomes is an aspect common to other Lippia species (Argyropoulou et al. 2010, Combrinck et al. 2007). Tozin et al. (2015) demonstrated that not all morphotypes of glandular trichomes of $L$. origanoides produce essential oils. Therefore, the more-abundant glandular trichomes in leaves in individuals from the campo cerrado are probably not secretors of essential oils. We can still suggest that under the environmental conditions of the campo cerrado there is a higher investment in the production of other types of substances by the glandular trichomes, and this provides greater protection against high light intensity and lower relative humidity. Hydrophilic substances can act as a lubricant in dry environments and facilitate leaf expansion (Ascensão et al. 1999). In Lippia species, phenolic compounds are abundant and variable in constitution (Pascual et al. 2001), and may help to protect against intense UV-B radiation resulting from greater exposure to sunlight (Liakoura et al. 1997).

Our results also showed that L. origanoides inflorescences had a higher density of glandular trichomes and produced a higher yield of essential oils in comparison to the leaf blades of individuals in the same environment. These data contrast with studies on other species, which reported a low yield of essential oils in flowers and inflorescences in comparison to leaves (Bassole et al. 2005, Parra-Gárces et al. 2010), and can be related to the different roles of these glands in reproductive organs (Ascensão et al. 1999, Paiva and Martins 2011). We suggest that in $L$. origanoides, the trichomes in the inflorescences are mainly involved in the production of large amounts of essential oils that play an important role in protecting the reproductive organs against herbivores and pathogens (Stökl et al. 2010). In addition, several terpenes can be reused in the plant metabolism (Harborne 1988), acting as precursors in the synthesis of hormones such as flowering hormones (Danilova and Kashina 1987, Roshchina and Roshchina 1993).

Chemical analysis of the essential oils in leaves and inflorescences of $L$. origanoides revealed a wide variation in the chemical composition of the essential oil among the individuals in each area. This may be related to genetic variability among individuals from these populations. Catalan and Lampasona (2002) found that intraspecific variations in the chemical composition of essential oils are common in species of Lippia.

Studies with L. origanoides (sensu lato) individuals have presented widely divergent chemical profiles. Thymol, carvacrol and p-cymene have been reported as the majority compounds (Cavalcanti et al. 2010, Oliveira et al. 2007, Stashenko et al. 2010, 2013). However, in this study, thymol and carvacrol were not found, while p-cymene was detected in small quantities. These findings are in accordance with the information reported by Rodrigues et al. (2011) and Stashenko et al. (2010), who demonstrated very divergent chemical profiles in this species. The wide variety of chemotypes found in L. origanoides may be a factor of the synonymization proposed by O'Leary et al. (2012); in a revision of the Goniostachyum section of Lippia, the authors synonymized 41 species into only four. The taxon that is presently known as $L$. origanoides results from the synonymization of 28 taxa that were formerly considered to be separate species (O’Leary et al. 2012).

In some individuals of $L$. origanoides, $\alpha$-pinene was found in large quantities in the inflorescences. This may be associated with the known role of this substance in attracting pollinators (Stökl et al. 2010). However, the inflorescences of some L. origanoides individuals did not contain this compound in large quantities, perhaps because of 
phenological differences among the individuals. Studies indicate that some compounds, such as carvone, limonene and $\beta$-pinene (Bicas et al. 2008) can volatilize or be utilized as precursors in the formation of other substances after the anthesis (Parra-Garcés et al. 2010, Stökl et al. 2010).

Trans-caryophyllene and $\alpha$-humulene were among the major compounds in leaves and inflorescences from several individuals. These substances show several important biological activities, including anti-inflammatory, analgesic, and others (Fernandes et al. 2007, Sabulal et al. 2006), and they are used to manufacture soaps, detergents and food products (Standen et al. 2006).

Individual number 3 from the campo cerrado, situated on an ant colony, diverged most widely from the others in oil yield and chemical composition; only this individual contained 1,8-cineole as the major compound, in both the inflorescences (52.2\%) and the leaves (58.2\%). The abundant production of this substance can be related to ant attacks on this individual, since 1,8-cineole is toxic to herbivorous insects (Prates et al. 1998, Sukontason et al. 2004). This toxic substance penetrates the insect body via the respiratory or digestive system, and is lethal to several animal species (Sukontason et al. 2004).

These findings evidenced the occurrence of variability in the glandular density in leaves of $L$. origanoides plants living in different areas. Our data demonstrated the chemical plasticity of this species, which can produce essential oils with differential chemical composition in distinct environments and evidenced the differential answers between leaves and inflorescences in a same individual. In view of this plasticity, the use of this species should be better monitored, particularly in popular medicine.

\section{ACKNOWLEDGMENTS}

We thank Fundação de Amparo à Pesquisa do Estado de São Paulo (FAPESP) (TEM/BIOTA Proc. 2008/55434-7) for financial support; PROPE/ FUNDUNESP (Proc. 0504/011/14) for supporting the review service of the manuscript; the technical team of the Centro de Microscopia Eletrônica(CME), IBB, UNESP, for helping in the sample preparation; and Dr. Luiz Fernando Rolim de Almeida, IBB, UNESP, for assistance with statistical analyses.

\section{RESUMO}

Os óleos essenciais de folhas e inflorescências de Lippia origanoides Kunth apresentam potencial aromático e medicinal e têm sido utilizados no tratamento de diversas doenças, incluindo melanoma. No Brasil, L. origanoides é comumente encontrada no campo cerrado e no cerrado stricto sensu, fisionomias caracterizadas principalmente pelas diferentes condições de luminosidade às quais as plantas de médio e pequeno porte estão sujeitas. Nosso objetivo foi investigar a densidade de tricomas glandulares e o rendimento e a composição química do óleo essencial em folhas e inflorescências de $L$. origanoides do campo cerrado e do cerrado stricto sensu. Para análise de densidade glandular, folhas e inflorescências foram processadas segundo técnicas convencionais em microscopia eletrônica de varredura. Os óleos essenciais de folhas e inflorescências foram obtidos por hidrodestilação e identificados com cromatografia gasosa. Brácteas e sépalas mostraram a maior densidade glandular, seguidas por pétalas e folhas. A densidade glandular na face abaxial do limbo foliar foi maior em indivíduos do campo cerrado. Em ambas as fisionomias, o rendimento de óleos essenciais foi maior nas inflorescências em comparação com folhas. A composição química dos óleos essenciais variou entre os indivíduos de diferentes áreas e entre indivíduos da mesma população. Nossos resultados demonstraram a plasticidade química de L. origanoides sugerindo a importância do monitoramento de seu uso popular.

Palavras-chave: campo cerrado, cerrado stricto sensu, glândulas externas, terpenos.

\section{REFERENCES}

ADAMS RP. 2007. Identification of essential oil components by gas chromatography/mass spectroscopy, Allured Publ. Corp, Carol Stream, 804 p. 
ARGYROPOULOU C, AKOUMIANAKI-LOANNIDOU A, CHRISTODOULAKIS SN AND FASSEAS C. 2010. Leaf anatomy and histochemistry of Lippia citriodora (Verbenaceae). Aust J Bot 58: 398-409.

Argyropoulou C, DAFERERa D, TARAntilis PA, Fasseas C AND Polissiou M. 2007. Chemical composition of the essential oil from leaves of Lippia citriodora H.B.K. (Verbenaceae) at two developmental stages. Biochem Syst Ecol 35: 831-837.

AsCEnsão L, Mota L AND CASTRO MM. 1999. Glandular trichomes on the leaves and flowers of Plectranthus ornatus: morphology, distribution and histochemistry. Ann Bot 84: 437-447.

Bassole IHN, Nebie R, SaVadogo A, OUattara CT, Barro N AND TRAORE NA. 2005. Composition and antimicrobial activities of the leaf and flower essential oils of Lippia chevalieri and Ocimum canum from Burkina Faso. Afr J Biotechnol 4: 1156-1160.

Bicas JL, Fontanille P, Pastore GM And Larroche C. 2008. Characterization of monoterpene biotransformation in two pseudomonads. J Appl Microbiol 105: 1991-2001.

CATALAN CAN AND LAMPASONA PDE. 2002. The chemistry of the genus Lippia (Verbenaceae). In: KINTZIOS SE (Eds), Oregano: The Genera Origanum and Lippia, Taylor and Francis; London, p. 127-149.

Cavalcanti SCH, Niculau ES, Blank AF, CÂmara CAG, ARAÚJO IN AND ALVES PB. 2010. Composition and acaricidal activity of Lippia sidoides essential oil against two-spotted spider mite (Tetranychusurticae Koch). Bioresour Technol 101: 829-832.

Combrinck S, Du Plooy GW, McCRINDle RI AND Botha BM. 2007. Morphology and histochemistry of glandular trichomes of Lippia scaberrima (Verbenaceae). Ann Bot 99: 1111-1119.

Craveiro AA, Fernandes AG, Andrade CHS, Matos FJA, ALENCAR JW AND MACHADO MIL. 1981. Óleos Essenciais de Plantas do Nordeste. UFC, Fortaleza, 209 p.

DANILOVA MF AND KASHINA TK. 1987. Ultrastructure of glandular squamule of Perilla ocymoides (Lamiaceae) in connection with their participance in the synthesis of steroid hormones and gibberellins. Phytomorphol 72: 427-435.

Fernandes ES, Passos GF, Medeiros R, Cunha FM, FERREIRA J, CAMPOS MM, PIANOWSKI LF AND CALIXTO JB. 2007. Anti-inflammatory effects of compounds alphahumulene and (-)-trans-caryophyllene isolated from the essential oil of Cordia verbenacea. Eur J Pharmacol 569: 228-236.

GIANFAgNA TJ, CARTER CD AND SACALIS JN. 1992 Temperature and photoperiod influence trichome density and sesquiterpene content of Lycopersicon hirsutum $\mathrm{f}$. hirsutum. Plant Physiol 100: 1403-1405.

GoBBO-Neto L AND LOPES NP. 2007. Plantas medicinais: Fatores de influência no conteúdo de metabólitos secundários. Quím Nova 30: 374-381.
GOMES GA, MONTEIRO CMO, SENRA TOS, ZERINGOTA V, CALmon F, Matos RS, DAEMon E, Gois RWS, SANTIAGO GMP AND CARVAlHo MG. 2012. Chemical composition and acaricidal activity of essential oil from Lippia sidoides on larvae of Dermacentor nitens (Acari: Ixodidae) and larvae and engorged females of Rhipicephalus microplus (Acari: Ixodidae). Parasitol Res 111: 2423-2430.

GonzÁles WL, NegritTo MA, SUÁREZ LH AND Gianoli E. 2008. Induction of glandular and non-glandular trichomes by damage in leaves of Madia sativa under contrasting water regimes. Acta Oecol 33: 128-132.

HARBORNE JB. 1988. The Flavonoids: Advances in Research since 1980. Chapman and Hall, New York.

Horgan FG, QUiring DT, LAgnaOUi A AND PELletier Y. 2009. Effects of altitude of origin on trichome-mediated anti-herbivore resistance in wild Andean potatoes. Flora 204: 49-62.

Judd WS, CAmpbell CS, Kellogg EA, Stevens PF And Donoghue MJ. 2009. Sistemática Vegetal: Um Enfoque Filogenético. $3^{\mathrm{a}}$ ed., Artmed, Porto Alegre.

JUliani Jr HR, KOROCH AR, JULIANI HR, TRIPPI VS AND ZYGADLO JA. 2002. Intraspecific variation in leaf oils of Lippia junelliana (Mold.) Tronc. Biochem Syst Ecol 30: 163-170.

Liakoura V, STEPFANOU M, MANETAS Y, CHOLEVAS C AND KARABOURNIOTIS G. 1997. Trichome density and its UV-B protective potential are affected by shading and leaf position on the canopy. Environ Exp Bot 38: 223-229.

Maroni BC, Di Stasi LC AND Machado SR. 2006. Plantas Medicinais do Cerrado de Botucatu - Guia Ilustrado. Editora UNESP, São Paulo.

MARTÍNEZ-NATARÉN DA, PARRA-TABLA V, DZIB G AND CALVO-IRABIÉN LM. 2011. Morphology and density of glandular trichomes in populations of Mexican oregano (Lippia graveolens H.B.K., Verbenaceae), and the relationship between trichome density and climate. J Torrey Bot Soc 138: 134-144.

O'Leary N, Denham SS, SAlimena F AND Múlgura ME. 2012. Species delimitation in Lippia section Goniostachyum (Verbaneceae) using the phylogenetic species concept. Bot J Linn Soc 170: 197-219.

Oliveira DR, Leitão GG, Bizzo HR, LOPES D, ALVIANo DS, Alviano CS AND Leitão SG. 2007. Chemical and antimicrobial analyses of essential oil of Lippia origanoides H.B.K. Food Chem 101: 236-240.

PAIVA EAS AND MARTINS LC. 2011. Calycinal trichomes in Ipomoea cairica (Convolvulaceae): ontogenesis, structure and functional aspects. Aust J Bot 59: 91-98.

PARRA-GARCÉS MI, CAROPRESE-ARAQUE JF, ARRIETA-PRIETO D AND STASHENKO E. 2010. Morfología, anatomia, ontogenia y composición química de metabolitos secundários em inflorescencias de Lippia alba (Verbenaceae). Rev Biol Trop 58: 1533-1548.

Pascual ME, Slowing K, CARretero E, Mata DM AND VILLAR A. 2001. Lippia: traditional uses, chemistry and pharmacology: a review. J Ethnopharmacol 6: 201-214. 
PÉreZ-Estrada LB, CANO-SANTANA Z AND OyAmA K. 2000. Variation in leaf trichomes of Wigandia urens: environmental factors and physiological consequences. Tree Physiol 20: 629-632.

Prates HT, Santos JP, Waquil JM, Fabris JD, Oliveira AB AND FOSTER JE. 1998. Insecticidal activity of monoterpenes against Rhyzopertha dominica (F.) and Tribolium castaneum (Herbst). J Stored Prod Res 34: 243249.

RoBARDS AW. 1978. An introduction to techniques for scanning electron microscopy of plant cells. In: Electron Microscopy and Cytochemistry of Plant Cells. HALL JL (Ed), Elsevier, New York.

Rocha-GuZMÁn NE, GAllegos-INFANTE JA, GONZÁleZLAREDO RF, RAMOS-GÓMEZ M, RODRÍGUES-MUÑOZ ME, REYNOSO-CAMACHO R, ROCHA-URIBE A AND ROQUEROSALES MR. 2007. Antioxidant effect of oregano (Lippia berlandieri v. Shauer) essential oil and mother liquors. Food Chem 102: 330-335.

Rodrigues FFG, COUTINHO HDM, CAMPOS AR, LiMA SG AND COSTA JGM. 2011. Antibacterial activity and chemical composition of essential oil of Lippia microphylla Cham. Acta Scient Biol Sci 33: 141-144.

RoshchinA VV AND RoshchinA VD. 1993. The Excretory Function of Higher Plants. Springer, Berlin.

Sabulal B, Dan M, John AJ, Kurup R, Pradeep NS, VALSAMmA RK AND GEORGE V. 2006. Caryophyllenerich rhizome oil of Zingiber nimmonii from South India: Chemical characterization and antimicrobial activity. Phytochem 67: 2469-2473.

SHeue CR, YANG YP AND KUO-HuANG LL. 2003. Altitudinal variation of resin ducts in Pinus taiwanesis Hayata (Pinaceae) needles. Bot Bull Acad Sin 44: 305-313.

SouZA VC AND LoRENZI H. 2008. Botânica sistemática: guia ilustrado para identificação das famílias de Angiospermas da flora brasileira, baseado em APG II. $2^{\text {a }}$ Ed., Instituto Plantarum, Nova Odessa.

STANDEN MD, ConNellan PA AND LEACH DN. 2006. Natural killer cell activity and lymphocyte activation: Investigating the effects of a selection of essential oils and components in vitro. Int J Aromather 16: 133-139.

STASHENKO EE, MARTÍNEZ JR, CALA MP, DURÁN DC AND CABALlERO D. 2013. Chromatographic and mass spectrometric characterization of essential oils and extracts from Lippia (Verbenaceae) aromatic plants. J Sep Sci 36: 192-202.
STASHEnko EE, Martinéz JR, Ruíz CA, Arias G, DURÁN C, Salgar W AND CALA M. 2010. Lippia origanoides chemotype differentiation based on essential oil GC-MS and principal component analysis. J Sep Sci 33: 93-103.

STÖKL J, BRODMANN J, DAFNI A, AYASSE M AND HANSSON BS. 2010. Smells like aphids: orchid flowers mimic aphid alarm pheromones to attract hoverflies for pollination. Proc Royal Soc B Biol Sci: doi:10.1098/rspb.2010.1770.

SUKONTASON KL, BOONCHU N, SUKONTASON K AND CHоосноте W. 2004. Effects of eucalyptol on house fly (Diptera: Muscidae) and blow fly (Diptera: Calliphoridae). Rev Inst Med Trop S Paulo 46: 97-101.

TOZIN LRS, CARVAlHo SF, Machado SR AND RodrigueS TM. 2015. Glandular trichome diversity on leaves of Lippia origanoides and Lippia stachyoides (Verbenaceae): morphology, histochemistry, and ultrastructure. Botany 93: 297-306.

VAN DEN DoOl H AND KRATZ DJ. 1963. A generalization of the retention index system including liner temperature programmed gas-liquid partition chromatography. J Chromatogr 11: 463-467.

VERAS HNH, ARARUNA MKA, COSTA JGM, COUTINHO HDM, KERNTOPF MR, BotelHo MA AND MENEZES IRA. 2013. Topical antiinflammatory activity of essential oil of Lippia sidoides Cham: Possible mechanism of action. Phytother Res 27: 179-185.

VilJoen AM, Subramoney S, VAN VuUREN SF, BASER KHC AND DERMIRCI B. 2005. The composition, geographical variation and antimicrobial activity of Lippia javanica (Verbenaceae) leaf essential oils. J Ethnopharmacol 96: 271-277.

Werker E. 2000. Trichome diversity and development. Pages 1-35. in Hallahan DL, JC Gray, eds. Plant Trichomes. Advances in Botanical Research 31, Academic Press, New York.

YAMAURA T, TANAKAS AND TABATAM. 1989. Light-dependent formation of glandular trichomes and monoterpenes in Thyme seedlings. Phytochem 32: 741-744. 
